\title{
Phosphate Solubilization and Changes of Certain Attributes in Soils as Affected by Bio-organic Fertilizers
}

\author{
M.M. El-Shinnawi ${ }^{1}$, M.A. El-Howeity ${ }^{2}$ and Amira E. El- \\ Meselawe $^{3}$ \\ ${ }^{I}$ Fac. of Agric., Minufiya University, Shibin El-Kom., ${ }^{2}$ Envir. \\ Stud. \& Res. Inst., University of Sadat City and ${ }^{3}$ Soil Improv. \\ Auth., Minuf. Branch, Ministry of Agriculture, Egypt.
}

$\mathbf{T}$

HE PRESENT work was planned to study the influence of bioorganic additives, i.e. compost "CM" and farmyard manure "FYM", as organic fertilizers, Bacillus megaterium " $\mathrm{Bm}$ " and Bacillus polymyxa "Bp", as biofertilizers, on phosphate solubilization and certain attributes in sandy and alluvial clayey soils, periodically along 120 day incubation, in pot experiments, under greenhouse conditions.

Results showed that, all added amendments increased phosphate solubilization in both soils with time of incubation. Incorporation of CM or FYM plus each of the biofertilizers greatly augmented phosphate solubilization, as compared with the single additive of each of the bio-organics. The increases resulted by using CM or FYM each with $B m$, reached $105 \& 62 \%$ and $88 \& 51 \%$ above the control treatment in the sandy and clay soils, respectively. Treatments included the $B p$, either alone or collaborated, despite their positive action, they gave lower values than those of the $B m$.

Addition of CM or FYM slightly decreased the $\mathrm{pH}$ values of both soils, at the first period and somewhat had recovered towards the end of experimental duration. However, all amendments revealed inconsistence among the applied treatments on soil reaction " $\mathrm{pH}$ value", generally within the succeeding intervals of incubation time. Nevertheless, the organic fertilizers generally excelled the biofertilizers, as well as combinations of the bio-organic treatments were thus more efficient in such concern (modifying the soil $\mathrm{pH}$ ). Introduction of $\mathrm{CM}$ or $\mathrm{FYM}$, each with $\mathrm{Bm}$ increased the concentration of the total soluble salts "TSS" by $48 \& 59 \%$ and $65 \&$ $80 \%$ above the control, in the sandy and clayey soils, respectively. Combination between the CM or FYM with the $B m$ resulted in lower increases, i.e. $40 \& 52 \%$ and $55 \& 66 \%$, evolution rate of $\mathrm{CO} 2$ augmented progressive with incubation time, when the clay soil excelled the sandy one, as the extents were $114 \& 92 \%$ and $76 \& 65 \%$ for $\mathrm{CM}+B m, \mathrm{CM}+\mathrm{BP}, \mathrm{FYM}+B m$ and $\mathrm{FYM}+B P$, respectively. Generally, the single addition of each of the bio-organic fertilizer was lower effective than the combined treatments.

Keywords: Compost, Farmyard manure, Bacillus megaterium, Bacillus polymyxa, Total soluble salts, $\mathrm{CO}_{2}$ evolution. 
Organic matter plays an important role in improving the physical, chemical and biological properties of soils. It substantially contributes to the fertility of soil providing plant nutrient via its decomposition, by increasing cation exchange capacity and water holding capacity, as well as its buffering action (Tisdale et al., 1993). Phosphorous is an essential nutrient for growth and productivity of plants. It plays an important role in plants in many physiological activities such as cell division, photosynthesis, energy reaction, and development of good root system and utilization of carbohydrate. Microorganisms enhance the $P$ availability to plants by mineralizing organic Pin soil and by solubilizing precipitated phosphates (Chen et al., 2006). Dissimilation of phosphate from organic compounds takes place through the enzyme" phosphatase" which is present in a wide variety of soil microorganisms . Plant can absorb phosphate only in soluble form. The transformation of insoluble phosphate into soluble form is carried out by a number of microbes present in the soil. A large fraction of soil microbes can dissolve insoluble inorganic phosphates present in the soil and makes them available to the plants (Youssef et al., 1999). Release of P by PSB from its insoluble and fixed / adsorbed forms is an important aspect regarding $\mathrm{P}$ availability in soils. There are strong evidences that soil bacteria are capable of transforming soil $\mathrm{P}$ to forms available to plants (Richardson, 2001).

The present work was designed to study the impact of bio-organic fertilizers, namely compost and farmyard manure as organic fertilizers, and Bacillus megaterium and Bacillus polymyxa as biofertilizers, on phosphate solubilization from the rock phosphate added to alluvial and sandy soils. Other concerned soil attributes were also tested.

\section{Materials and Methods}

\section{Materials employed}

Soils

Soil samples were collected from the surface layer $(0-30 \mathrm{~cm})$ of two locations in Minufiya Governorate of Egypt, namely:

1) Sandy soil, from the Experimental Farm of the Environmental Studies \& Research Institute, University of Sadat City.

2) Alluvial non- saline soil, from the Experimental Farm of the Faculty of Agriculture, Minufiya University, Shibin El - Kom.

Soil samples were analyzed, following the standard methods stated by Cottenie et al. (1982), and Klute (1986), and the data are presented in Table 1.

\section{Rock phosphate}

Rock phosphate "Fluoro apatite, $\mathrm{Ca}_{10} \mathrm{~F}_{2}\left(\mathrm{PO}_{4}\right)_{6}$ ", was used as a source of insoluble phosphate mineral fertilizer, having a $\mathrm{pH}$ value 7.9 (1:2.5, water suspension ) and phosphorus content of $10.5 \%$. 
PHOSPHATE SOLUBILIZATION AND CHANGES OF CERTAIN ...

TABLE 1. Physical and chemical properties of the soils tested.

\begin{tabular}{|c|c|c|c|c|}
\hline \multicolumn{3}{|c|}{ Property } & Sandy soil & Alluvial soil \\
\hline \multirow{3}{*}{\multicolumn{2}{|c|}{ Particle size distribution, $\%$}} & Sand & 88.5 & 25.0 \\
\hline & & Silt & 8.9 & 28.2 \\
\hline & & Clay & 2.6 & 46.8 \\
\hline \multicolumn{3}{|c|}{ Textural grade } & Sandy & Clayey \\
\hline \multicolumn{3}{|c|}{ W.H.C. , \% } & 30 & 60 \\
\hline \multicolumn{3}{|c|}{$\mathrm{pH}, 1: 2.5$ (soil: water susp.) } & 7.81 & 7.58 \\
\hline \multicolumn{3}{|c|}{ C E C, meq $100 \mathrm{~g}^{-1}$ Soil } & 6.90 & 29.80 \\
\hline \multicolumn{3}{|c|}{ E.C, $\mathrm{dSm}^{-1}$ (1:5, soil: water extr.) } & 0.28 & 0.62 \\
\hline \multirow{8}{*}{ 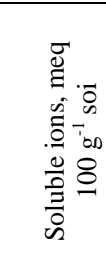 } & \multirow[b]{4}{*}{ Cations } & $\mathrm{Ca}^{++}$ & 0.11 & 0.28 \\
\hline & & $\mathrm{Mg}^{++}$ & 0.05 & 0.36 \\
\hline & & $\mathrm{Na}^{+}$ & 0.13 & 2.45 \\
\hline & & $\mathrm{K}^{+}$ & 0.01 & 0.15 \\
\hline & \multirow{4}{*}{ Anions } & $\mathrm{Cl}^{-}$ & 0.03 & 0.48 \\
\hline & & $\mathrm{HCO}^{-}$ & 0.10 & 0.58 \\
\hline & & $\mathrm{CO}^{2}=$ & - & - \\
\hline & & $\mathrm{SO}^{=}=$ & 0.15 & 2.09 \\
\hline \multicolumn{3}{|c|}{$\mathrm{Ca} \mathrm{CO}_{3}, \%$} & 2.37 & 2.10 \\
\hline \multicolumn{3}{|c|}{ Organic matter, $\%$} & 0.60 & 1.42 \\
\hline \multicolumn{3}{|c|}{ Total N, \% } & 0.05 & 0.15 \\
\hline \multicolumn{3}{|c|}{ Total P, \% } & 0.03 & 0.10 \\
\hline \multicolumn{3}{|c|}{ Total K, \% } & 0.15 & 0.31 \\
\hline \multicolumn{3}{|c|}{ Soluble $\mathrm{N}, \mathrm{mg} \mathrm{kg}^{-1}$} & 13.9 & 58.11 \\
\hline \multicolumn{3}{|c|}{ Soluble $\mathrm{P}, \mathrm{mg} \mathrm{kg}^{-1}$} & 8.53 & 11.04 \\
\hline \multicolumn{3}{|c|}{ Soluble $\mathrm{K}, \mathrm{mg} \mathrm{kg}^{-1}$} & 60.10 & 270.00 \\
\hline
\end{tabular}

Organic fertilizers

Compost "CM" and farmyard manure "FYM" were chosen as sources of organic fertilizers. Data of chemical analysis of these organic sources are presented in Table 2.

TABLE 2. Chemical properties of the organic fertilizers used .

\begin{tabular}{|l|c|c|c|c|c|c|c|}
\hline $\begin{array}{c}\text { Organic } \\
\text { fertilizers }\end{array}$ & $\begin{array}{c}\mathbf{p H} \\
*\end{array}$ & $\begin{array}{c}\mathbf{E . C} * * \\
\mathbf{d S m}^{-1}\end{array}$ & $\begin{array}{c}\text { Organic } \\
\mathbf{C} \%\end{array}$ & $\begin{array}{c}\text { Total N } \\
\mathbf{\%}\end{array}$ & $\begin{array}{c}\text { C:N } \\
\text { ratio }\end{array}$ & $\begin{array}{c}\text { Total } \\
\mathbf{P} \text { \% }\end{array}$ & $\begin{array}{c}\text { Total } \\
\mathbf{C a} \%\end{array}$ \\
\hline $\begin{array}{l}\text { Compost } \\
\text { "CM" }\end{array}$ & 7.62 & 2.46 & 17.28 & 1.21 & 14.3 & 0.52 & 0.61 \\
\hline $\begin{array}{l}\text { Farmyard } \\
\text { manure } \\
\text { "FYM" }\end{array}$ & 7.86 & 5.10 & 13.01 & 0.72 & 18.1 & 0.32 & 1.12 \\
\hline
\end{tabular}

$* \mathrm{pH}:$ In the $1: 10$ water suspension.

**E.C, $\mathrm{dSm}^{-1}$ In the $1: 10$ water extract.

\section{Biofertilizers}

The microorganisms, namely Bacillus megaterium "Bm" and Bacillus polymyxa " $B p$ " were employed herein as phosphate solubilizing bacterial agents. 
Plan of work

The experiments were conducted in the research greenhouse of the Soil Improvement Authority, Minufiya Branch. Samples of the sieved sandy or clayey soil were thoroughly mixed with the powdered rock phosphate, at a rate of $1000 \mathrm{ppm} \mathrm{P} \mathrm{(mg} \mathrm{Kg} \mathrm{soil}{ }^{-1}$ ), and CM or FYM, as sources of organic fertilizers at a rate of $2 \%$ organic carbon basis. Plastic pots were used, each contained 500 $\mathrm{g}$ of the treated soil. The potted soils then received each biofertilizer inoculum, at a rate of $2 \mathrm{ml} /$ pot (containing $10^{3}-10^{4}$ cell $\mathrm{ml}^{-1}$ per $\mathrm{ml}$ ). Each experimental treatment was replicated three times. Moisture content of the potted soils was kept at the field capacity of each treated soil. Pertinent chemical and biological associating attributes of the treated soils had been determined at intervals along 120 day- incubation period at the ambient temperature.

\section{Preparation of the biofertilizers}

The strains of either Bacillus megaterium or Bacillus polymyxa were precultured on nutrient agar media, then each was grown in a nutrient broth liquid medium for 2 days at $30^{\circ} \mathrm{C}$. The suspended cultures were then centrifugated at $1000 \mathrm{rpm}$ for $30 \mathrm{~min}$., at $10^{\circ} \mathrm{C}$. The sediment was re-suspended in $5 \mathrm{ml}$ sterilized $0.8 \% \mathrm{KCl}$ solution $(\mathrm{w} / \mathrm{v})$. The bacterial suspension was again shacken for $5 \mathrm{~min}$., (Collins and Lyne, 1980). These suspensions were introduced as biofertilizer inoculants.

\section{Experimental treatments}

1- Control: Soil without any mineral $\mathrm{P}$ or bio-organic additives.

2- 1 "W.B.O" i.e. Soil + Rock phosphate "RP" without bio-organics.

3- Soil + Rock phosphate "RP"+ Compost "CM ".

4- Soil + Rock phosphate "RP"+ Farmyard manure "FY M".

5- $\quad$ Soil + Rock phosphate "RP" +Bacillus megaterium "Bm".

6- $\quad$ Soil + Rock phosphate "RP"+ Bacillus polymyxa "Bp".

7- $\quad$ Soil + RP + CM + Bm.

8- $\quad$ Soil $+\mathrm{RP}+\mathrm{CM}+B p$.

9- $\quad$ Soil + RP + FYM + Bm.

10- Soil + RP + FYM + BP.

Periodical laboratory measurements

Soil samples of each pot, were subjected to the following determinations every 15 day-intervals, up to 120 days.

Chemical assessments

The methods noted by Cottenie et al. (1982) had been carried out, as follows:

1) Organic carbon "O.C": by Walkely and Black method.

2) Soluble phosphates: by the Bray $\mathrm{P}-2$ method, using $\mathrm{NH}_{4} \mathrm{~F}+\mathrm{HCl}$ solution, following the Olsen method using $0.5 \mathrm{M} \mathrm{NaHCO}_{3}$ for extraction.

3) Soil reaction " $\mathrm{pH}$ ": in the 1:2.5 soil: water suspension, using $\mathrm{pH}-$ meter.

4) total soluble salts" EC" in the 1:5 soil -water extract, using an electrical conduct meter.

Egypt. J. Soil Sci. 55, No. 4 (2015) 
Overall microbial activity in soil (soil respiration)

To assess the overall microbial activity in soil, the daily evolution rate of $\mathrm{CO}_{2}$ had been measured every 15-day intervals up to 120 day experimental duration, according to the procedure of Paul and Clark (1996), by traping the $\mathrm{CO}_{2}$ evolved from the differently treated soils in $\mathrm{NaOH}$ solution, in an air -tight device, and back titration with HCL using $\mathrm{BaCL}_{2}$.

\section{Calculations}

Raw results (analytical data) of the various treatments were further calculated on the dry weight basis of the used substrates.

Rates of the relative changes of results (as percent) "RC \% "were calculated for the mean value listed for each treatment for all intervals, referring to the mean results of the control "W.B.O " ( Soil with RP and no bio-organics):

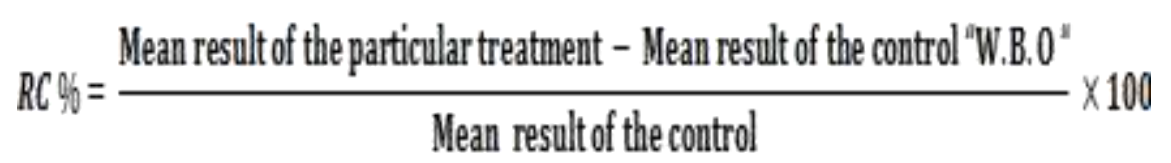

Statistical analysis

The data obtained were statistically analyzed (LSD, at $0.05 \& 0.01$ ), according to the method outlined by Sendecor and Cochran (1980).

\section{Results and Discussion}

Effect of the bio-organic additives on soluble phosphate contents in soils

Changes in the contents of soluble phosphtes by using the bio- organic additives, i.e. compost "CM" and farmyard manure "FYM", as well as Bacillus megaterium "Bm" and Bacillus polymyxa "Bp", periodically along 120 dayincubation, in the sandy and clayey soils, are presented in Table 3( a \& b). It is revealed that, all of the experimental amendments significantly increased phosphate solubilization from its insoluble rock phosphate "RP" in both soils with time of incubation. Data of Table (3a) show that, incorporation of CM or FYM increased the contents of soluble phosphorus, in the sandy soil to be expressed by the rates of relative change " $\mathrm{RC}$ " giving 48 \& $32 \%$ respectively, above the control without bio-organics "W.B.O", respectively. On the other hand, introduction of the biofertilizers " $\mathrm{Bm}$ " or " $\mathrm{BP}$ " improved phosphate solubilization from the source (RP) in the same soil by RC values of $21 \& 12 \%$, respectively. The greatest values of solubilized $\mathrm{P}$ were obtained by incorporating the dual addition of bio-and organic fertilizers. Application of CM with $B m$ gave the highest values, followed by $\mathrm{CM}+B p$, where $\mathrm{RC}$ values were $105 \& 82 \%$, respectively. Likewise, combination between FYM and any of the biofertilizers tested promoted phosphate solubilization, but the values were lower than those of the compost mixed with either bacterial strain. Increases, expressed by the RC values were $62 \& 42 \%$, referring to the control treatment, using FYM mixed with 
$\mathrm{Bm}$ and FYM with $\mathrm{Bp}$, respectively. The mean value of $\mathrm{RC}$ for all of the bioorganic treatments collectively was $38 \%$ above the mean value of the control "W.B.O" (without bio-organic addition).

TABLE 3a. Effect of the bio-organic additives on phosphate solubilization in the rock phosphate treated Sandy soil.

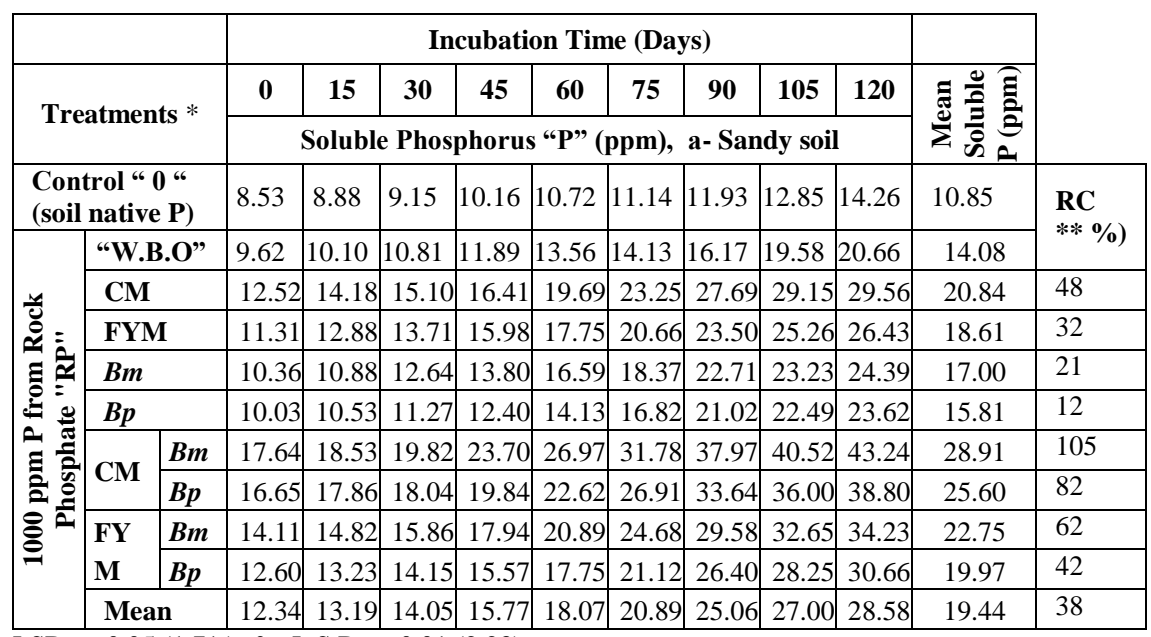

LSD, at 0.05 (1.71 ) \& L.S.D, at 0.01 (2.23).

*W.B.O.(without bio-organic addition), CM(compost), FYM(farmyard manure), Bm (Bacillus megaterium), Bp (Bacillus polymyx).

** RC: Rate of relative changes of the results, referring to the control "W.B.O ".

The same trend was observed for the clayey soil, where the soluble phosphorus contents increased progressively with time of incubation to give the highest values on the $120^{\text {th }}$ day (Table, 3b). Results also declared that, all treatments augmented the phosphate solubilization from its insoluble form (RP). Addition of CM or FYM, as sources of organic matter, together with $B m$ or $B p$, as bio-fertilizers, improved phosphate solubilization, to reach the RC values of $88,67,51$ and $31 \%$ by applying $\mathrm{CM}+B m, \mathrm{CM}+B p, \mathrm{FYM}+B m$ and $\mathrm{FYM}+B p$, respectively.

The mean $\mathrm{RC}$ value for the mean $\mathrm{RC}$ value of all treatments was $28 \%$ above the control "W.B.O". In this connection, the sandy soil showed higher rates of phosphate solubilization than the clayey soil. 
TABLE 3b. Effect of the bio-organic additives on phosphate solubilization in the rock phosphate treated Clay soil.

\begin{tabular}{|c|c|c|c|c|c|c|c|c|c|c|c|c|c|}
\hline & & & \multicolumn{9}{|c|}{ Incubation Time (Days) } & \multirow{3}{*}{ 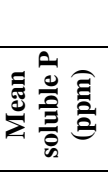 } & \\
\hline \multirow{2}{*}{\multicolumn{3}{|c|}{ Treatments * }} & $\mathbf{0}$ & 15 & 30 & 45 & 60 & 75 & 90 & 105 & 120 & & \\
\hline & & & \multicolumn{9}{|c|}{ Soluble Phosphorus “ $\mathbf{P}$ “ (ppm), b- Clayey Soil } & & \\
\hline \multicolumn{3}{|c|}{$\begin{array}{l}\text { Control " } 0 \text { " } \\
(\text { soil native } \mathbf{P})\end{array}$} & 11.04 & 11.60 & 12.41 & 13.65 & 14.56 & 16.52 & 19.14 & 20.76 & 21.00 & 15.63 & \multirow{2}{*}{$\begin{array}{l}\mathbf{R C} * * \\
(\%)\end{array}$} \\
\hline \multirow{10}{*}{ 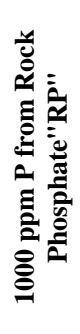 } & \multicolumn{2}{|c|}{ "W.B.O" } & 11.77 & 12.36 & 13.22 & 14.54 & 16.58 & 19.73 & 24.66 & 26.39 & 27.71 & 18.55 & \\
\hline & \multicolumn{2}{|c|}{ CM } & 15.35 & 16.12 & 17.25 & 18.97 & 21.63 & 25.78 & 32.67 & 34.82 & 36.54 & 24.35 & 31 \\
\hline & \multicolumn{2}{|c|}{ FYM } & 13.83 & 14.52 & 15.54 & \begin{tabular}{|l|}
17.09 \\
\end{tabular} & 19.49 & 23.19 & 28.99 & 31.02 & 32.57 & 21.80 & 18 \\
\hline & \multicolumn{2}{|c|}{$B m$} & 12.67 & 13.30 & 14.23 & 15.65 & 17.85 & 21.24 & 26.55 & 28.40 & 29.82 & 19.97 & 8 \\
\hline & \multicolumn{2}{|l|}{$B p$} & 12.27 & 12.88 & 13.78 & 15.16 & 17.28 & 20.57 & 25.71 & 27.51 & 28.88 & 19.34 & 4 \\
\hline & \multirow{2}{*}{$\mathbf{C M}$} & $\mathrm{Bm}$ & 21.57 & 22.65 & 25.24 & 28.68 & 32.40 & 38.67 & 45.76 & 48.48 & 50.80 & 34.92 & 88 \\
\hline & & $B p$ & 19.63 & 20.61 & 22.06 & 24.26 & 27.66 & 32.91 & 41.14 & 44.02 & 46.22 & 30.95 & 67 \\
\hline & \multirow{2}{*}{ FYM } & $B m$ & 17.26 & 18.92 & 19.59 & 22.83 & 25.32 & 29.94 & 36.17 & 39.70 & 41.64 & 27.93 & 51 \\
\hline & & $B p$ & 15.41 & 16.18 & 17.31 & \begin{tabular}{|l|}
19.04 \\
\end{tabular} & 21.70 & \begin{tabular}{|l|}
25.83 \\
\end{tabular} & 32.29 & 34.55 & \begin{tabular}{|l|}
36.27 \\
\end{tabular} & 24.29 & 31 \\
\hline & \multicolumn{2}{|c|}{ Mean } & 15.08 & 15.91 & 17.06 & 18.99 & 21.45 & 25.44 & 31.31 & 33.56 & 35.14 & 23.77 & 28 \\
\hline
\end{tabular}

$\mathrm{L} \mathrm{S} \mathrm{D,} \mathrm{at} 0.05(2.25) \& \quad$ L.S.D, at $0.01(2.98)$.

* W.B.O.(without bio-organic addition), CM(compost), FYM(farmyard manure), Bm (Bacillus megaterium), Bp (Bacillus polymyx).

** RC: Rate of relative changes of the results , referring to the control "W.B.O "

The data above noted indicated that, the phosphates extracted from the sandy or clayey soil treated with either organic matter source (compost "CM" or farmyard manure "FYM") and or phosphate solubilizing bacteria (Bacillus megaterium "Bm" or Bacillus polymyxa " $B p$ "), increased with time from the insoluble source (rock phosphate). Similar results were found by Das et al. (1995), who noted that phosphorus extractability increased with organic materials decomposition reaction period and substantial portion of the added phosphorus had been mineralized within 60 days of incubation. They added that after 120 days, the released phosphorus detected was more than the phosphorus added through sorghum residue at $50 \%$ field capacity condition. The effect of compost or farmyard manure application, as organic matter source, in the present study, on rock phosphate solubilization increased the soluble phosphate contents in both soils (sandy and clayey) with incubation time. This result is due actually to organic matter decomposition during which organic $\mathrm{P}$ is mineralized and released in soluble form, as well as production of carbonic and organic acids that plays a significant role in mobilizing the insoluble phosphate. Similar results were reported by Singh and Amberger (1997), as they found that humic and fulvic acids increased the solubility of rock phosphate, regardless, the effect of Bacillus megaterium and Bacillus polymyxa, as phosphate solubilizing bacteria, fulvic acids had $80 \%$ higher phosphorus solubilizing capacity than humic acids. The lower positive response of the clayey soil (RC value) to the applied bioorganic additives, than the sandy soil, could be due to its sorption- desorption capacity, controlling the equilibrium dynamics of phosphates in soil solution (Lindsay, 1979). 
Nahas (1996), Khan et al. (2007) and Muhammad \& Maram (2012) concluded that phosphate solubilizing bacteria "PSB" and organic fertilizers were effective on solubilizing rock phosphate, by decreasing the $\mathrm{pH}$ of the soil treated with rock phosphate, through production of carbonic and organic acids. Moreover, the polycarboxylic organic metabolites might hinder the activity of $\mathrm{Ca}$ cations via chelating reaction, in favour to $P$ solubilization.

Phosphorus sorption occurs primarily by the covalent bonding of phosphate ions to hydrous oxides of cations. There are many reactions involving cations in soils, however the discussion here is limited to those cations that significantly contribute to P solubility. In alkaline soils, calcium carbonates, as well as iron oxides are involved with $\mathrm{P}$ sorption, aluminium phosphates to convert to calcium phosphates. In the $\mathrm{pH}$ range $6-6.5$, several phosphate minerals can coexist, these include varisite, strengite, $\mathrm{CaHPO}_{4} \cdot 2 \mathrm{H}_{2} \mathrm{O}, \mathrm{CaHPO}_{4}$ and $\mathrm{Ca}_{4} \mathrm{H}\left(\mathrm{PO}_{4}\right)_{2}$. This appears to be the $\mathrm{pH}$ range in which phosphates are most available to plants. Desorpation will also occur usually from the more labile pools releasing P back into the soil solution (Lindsy, 1979).

Enhancing the availability of soil inorganic $\mathrm{P}$ to plant uptake is an important research subject, as well as with practical aspects. Reactive rock phosphates can provide a less expensive alternative to manufactured $\mathrm{P}$ fertilizers, but they are only slowly soluble in most soils. Direct application of natural phosphate may arise out of economic necessity, as in developing countries, or as part of an environmentally sound approach to soil nutrient plants, as in biological and organic production. Hence, there is a need to increase the effectiveness of lowreactive phosphate rocks. In general, the availability of nutrients contained in natural minerals depends on many factors, some of which are soil type, soil reaction $(\mathrm{pH})$, soil solution composition, plant species and types and ratios of microorganisms (Taalab and Badr, 2007).

It is well established that, application of rock phosphate is not economically feasible, particularly at soil conditions characterized by a high $\mathrm{P}$ sorption capacity, low cation exchange capacity, high $\mathrm{pH}$, low rainfall, low organic matter content, and low microbial activity (Simpson et al., 1997 and Vassilev et al., 2006). Such conditions are typically the case the Egyption soils (alluvial, calcareous and sandy). For these reasons, various strategies for RP solubilization have been recently proposed with an increasing emphasis on application of Psolubilizing microorganisms.

Effect of the Bio-organic Additives on Soil Reaction" $p H$ "

Changes in the soil reaction "pH" by using the bio-organic amendments, i.e. compost "CM" and farmyard manure" FYM", Bacillus megaterium "BM", and Bacillus polymyxa "BP", within 120 days of experimental duration for both tested soils (sandy and clayey), are shown in Table 4. All soil treatments slightly

Egypt. J. Soil Sci. 55, No. 4 (2015) 
decreased the soil $\mathrm{pH}$, especially at the first intervals up to 60 days of incubation time. Incorporation of CM or FYM diminished the $\mathrm{pH}$ values at first then modestly moved up towards the end of experimental period, with the CM giving lower values than the FYM. Introduction of the biofertilizers, revealed the same pattern, but at somewhat higher values, whereas $B m$ was mostly more effective on lowering the $\mathrm{pH}$ value than $B p$. Combinations of the organic and biofertilizers showed inconsistent changes of the $\mathrm{pH}$ values. However, the dual application of $\mathrm{CM}+\mathrm{Bm}$ (or $B P$ ) were generally more active in reducing the $\mathrm{pH}$ value than their FYM correspondents. This was the case in both soils tested. Generally, changes in the $\mathrm{pH}$ values of both soils detected throughout the experimental period were inconsiderable.

The initial $\mathrm{pH}$ values of the experimental substrates, namely soils and organic fertilizers (Tables $1 \& 2$ ) contributed to the alterations of $\mathrm{pH}$ values recorded within the duration of study. Moreover, amount added and composition of the used organics, i.e. compost and farmyard manure determined their rate decomposition (particularly the $\mathrm{C} / \mathrm{N}$ ratios) and contents of salts, which were reflected on the release of carbonic and organic acids at the first intervals of incubation time, then liberation of mineral elements latter on.

This explains the decrease of $\mathrm{pH}$ value at first, and the recovery occurring later on, as the rate of breakdown had declined by elapse of time. It was also reported that phosphate dissolving bacteria produce a number of organic acids that could participate in decreasing the $\mathrm{pH}$ value in soil (Khan et al., 2007). In this regard, it is assumed that phosphate solubilization extent and $\mathrm{pH}$ change in soil, as influenced by the bio-organic treatments, are governed by the net difference between the rates of organic acids formation and their decay in soil medium.

Worth mentioning that, in the $\mathrm{pH}$ range 6-6.5, several phosphate minerals can coexist, these include varisite, strengite, $\mathrm{CaHPO}_{4} \cdot 2 \mathrm{H}_{2} \mathrm{O}, \mathrm{CaHPO}_{4}$ and $\mathrm{Ca}_{4} \mathrm{H}$ $\left(\mathrm{PO}_{4}\right)_{2}$. This appears to be the $\mathrm{pH}$ range in which phosphates are most available to plants. Desorption would also occur usually from the more labile pools releasing P back into the soil solution (Lindsay, 1979).

It is well established that, the initial properties of arid soils, particularly texture, original $\mathrm{pH}$ value, cation exchange capacity and contents of each of organic matter, $\mathrm{CaCO} 3$ and soluble salts, are of prime roles, positively (decreasing ) or negatively (increasing ), in alteration of $\mathrm{pH}$ value under any modifying treatments( Brady and Weil, 2008).

The buffering capacity of the finely textured soil rich in organic matter limits the drastic changes of $\mathrm{pH}$ values that might occur under some circumstances. 
TABLE 4 a \& b. Effect of the bio-organic additives on soil reaction (pH) in the rock phosphate treated sandy and clay soils.

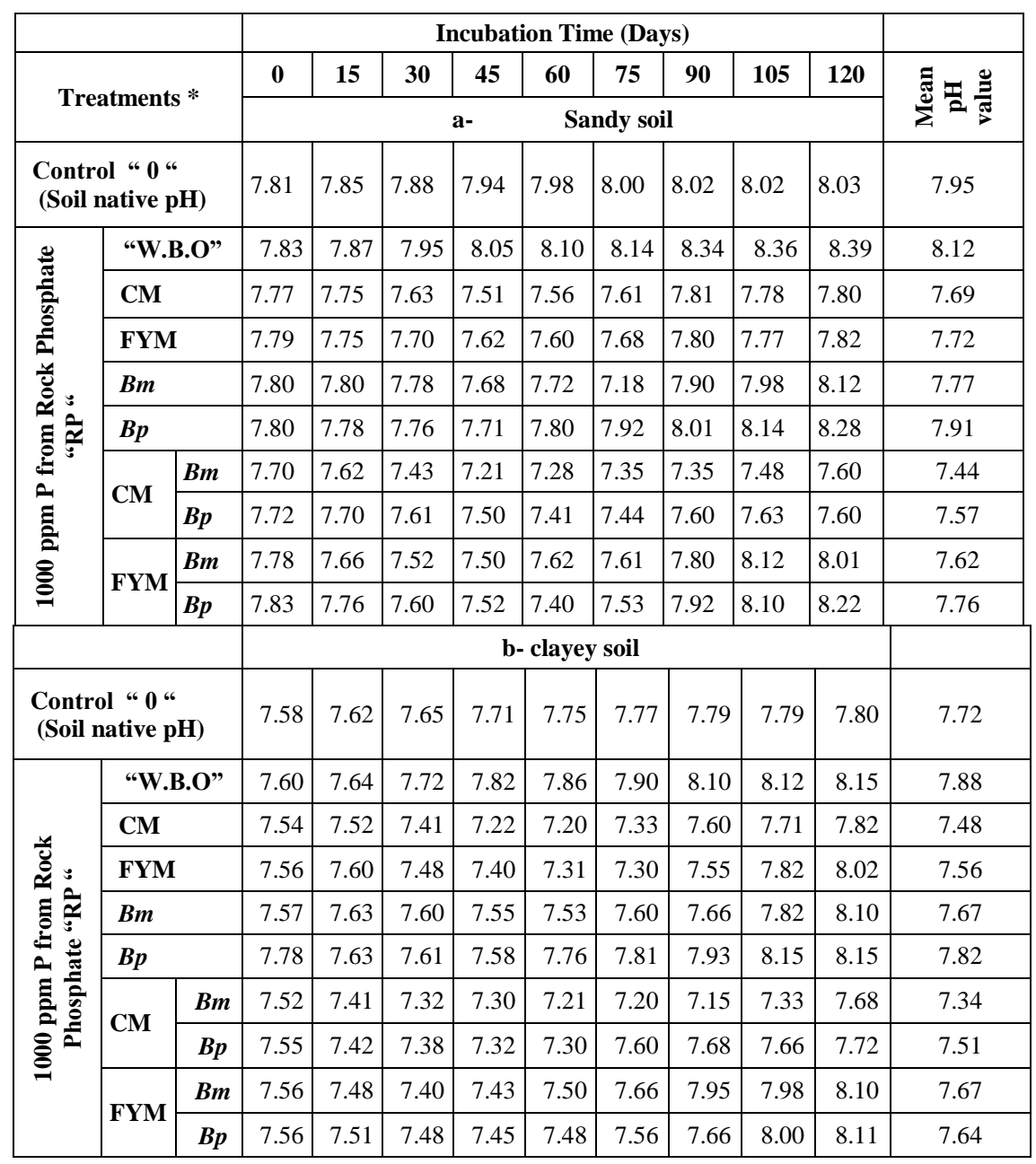

*W.B.O. (without bio-organic addition), CM (compost), FYM (farmyard manure), Bm (Bacillus megaterium), Bp (Bacillus polymyx).

Effect of the bio-organic additives on concentration of total soluble salts in soil

Concentration changes of the total soluble salts "TSS", as affected by using the bio-organic additives , i.e. compost "CM" and farmyard manure "FYM", Bacillus megaterium "Bm", Bacillus polymyxa "BP" during 120 day-incubation period of both treated soils (sandy and clayey), are presented in Table 5. The gained data revealed that, all the employed amendments resulted in progressive, mostly significant, increases of the concentration of TSS in the soils with incubation time. Incorporation of CM or FYM raised the levels of TSS in sandy soil by RC values of $20 \& 33 \%$ above the control, respectively (Table 5a). On

Egypt. J. Soil Sci. 55, No. 4 (2015) 
the other hand, introduction of the biofertilizers $B m$ slightly increased the TSS concentration (RC, $8 \%$ ), but the $B p$ showed mostly no alterations. The highest values of TSS were obtained by the dual addition of both organic and biofertilizers. Combination of $\mathrm{CM}+\mathrm{Bm}$ gave higher values than the double treatment of $\mathrm{CM}+B P$, as they gave $\mathrm{RC}$ values of $48 \& 40 \%$, in order. Likewise, combination of FYM+ each of $B m$ or $B P$ raised the content of TSS, but at somewhat higher values than those of the CM. Extents of increases, referring to the control treatment were RC $65 \& 55 \%$, for FYM+ Bm and FYM+ $B p$, respectively. The mean RC value of the bio-organic additions collectively was $25 \%$ (Table 5a).

Contents of TSS in the clayey soil exhibited a similar trend to that of the sandy soil, when increased with the time of incubation (Table 5b). Effect of CM \& FYM, as organic fertilizers, and Bm\& BP, as bio-fertilizers, augmented the level of TSS in soil solution. Such increases reached RC values of $28 \& 40$ and $11 \& 4 \%$, respectively.

TABLE 5a. Effect of the bio-organic additives on concentration of the total soluble salts "TSS" in the rock phosphate treated sandy soil.

\begin{tabular}{|c|c|c|c|c|c|c|c|c|c|c|c|c|c|}
\hline & & & & & Incub & ation $\mathrm{T}$ & ime (I & ays) & & & & & \\
\hline & eatmer & ts * & 0 & 15 & 30 & 45 & 60 & 75 & 90 & 105 & 120 & 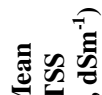 & \\
\hline & & & & l Sol & ble Sa & Its "Ts & S" Co & icent & ation & $\mathbf{C}, \mathbf{d}$ & $\left.m^{-1}\right)$ & & \\
\hline $\begin{array}{l}\text { Con } \\
\text { (Soi }\end{array}$ & trol " & $\begin{array}{l}\text { " } \\
\text { TSS) }\end{array}$ & 0.28 & 0.29 & 0.30 & 0.31 & 0.32 & 0.35 & 0.40 & 0.42 & 0.43 & 0.34 & $\begin{array}{l}\mathbf{R C} * * \\
(\%)\end{array}$ \\
\hline$\stackrel{\leftrightarrow}{a}$ & "W.B. & & 0.30 & 0.31 & 0.33 & 0.35 & 0.36 & 0.40 & 0.46 & 0.51 & 0.55 & 0.40 & \\
\hline 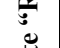 & CM & & 0.34 & 0.35 & 0.38 & 0.38 & 0.46 & 0.48 & 0.61 & 0.65 & 0.70 & 0.48 & 20 \\
\hline$\frac{\pi}{\pi}$ & FYM & & 0.34 & 0.38 & 0.40 & 0.41 & 0.56 & 0.54 & 0.65 & 0.73 & 0.77 & 0.53 & 33 \\
\hline$\stackrel{\tilde{g}}{a}$ & Bm & & 0.31 & 0.33 & 0.35 & 0.35 & 0.39 & 0.44 & 0.53 & 0.56 & 0.59 & 0.43 & 08 \\
\hline 글 & $B p$ & & 0.31 & 0.32 & 0.33 & 0.35 & 0.37 & 0.41 & 0.48 & 0.52 & 0.56 & 0.40 & 00 \\
\hline$\underline{\underline{\simeq}}$ & & $B m$ & 0.37 & 0.38 & 0.49 & 0.48 & 0.51 & 0.60 & 0.73 & 0.81 & 0.89 & 0.59 & 48 \\
\hline$\stackrel{\varrho}{\varrho}$ & C111 & $B p$ & 0.38 & 0.38 & 0.46 & 0.45 & 0.50 & 0.57 & 0.70 & 0.76 & 0.83 & 0.65 & 40 \\
\hline$\vec{A}$ & $5 \mathrm{TY}$ & $B m$ & 0.44 & 0.44 & 0.52 & 0.54 & 0.54 & 0.66 & 0.42 & 0.43 & 1.00 & 0.66 & 65 \\
\hline 2 & & $B p$ & 0.42 & 0.41 & 0.50 & 0.42 & 0.57 & 0.62 & 0.79 & 0.89 & 0.43 & 0.62 & 55 \\
\hline 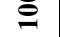 & & & 0.35 & 0.36 & 0.41 & 0.40 & 0.46 & 0.51 & 0.63 & 0.68 & 0.72 & 0.50 & 25 \\
\hline
\end{tabular}

L.S.D, at $0.05(0.07) \quad \& \quad$ L.S.D, at $0.01(0.10)$.

*W.B.O.(without bio-organic addition), CM ( compost ), FYM ( farmyard manure), Bm (Bacillus megaterium), Bp (Bacillus polymyxa).

** RC: Rate of relative changes of the results, referring to the control "W.B.O ". 
Incorporation of the combined additives, i.e. the bio- organic fertilizers, significantly raised the contents of TSS in the clayey soil, as they gave RC values of $59 \& 52$ and $80 \& 62 \%$, referring to the control treatment, for $\mathrm{CM}+\mathrm{Bm}$, $\mathrm{CM}+B p, \mathrm{FYM}+B m, \mathrm{FYM}+B P$, respectively. The mean $\mathrm{RC}$ value for the bioorganic additions recorded $32 \%$ collectively.

TABLE 5b. Effect of the bio-organic additives on concentration of the total soluble salts "TSS" in the rock phosphate treated clayey soil.

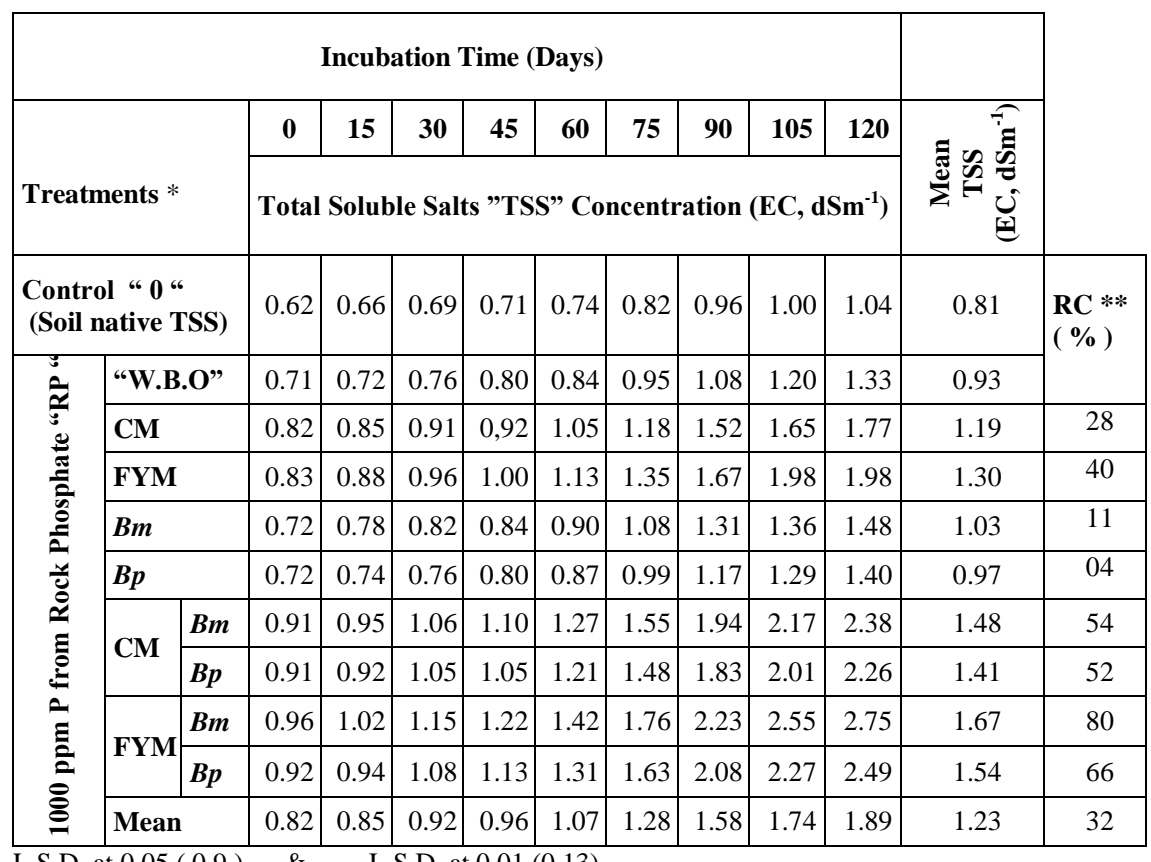

L.S.D, at $0.05(0.9) \quad \& \quad$ L.S.D, at $0.01(0.13)$.

*W.B.O (without bio-organic addition), CM ( compost ), FYM ( farmyard manure), Bm (Bacillus megaterium), Bp (Bacillus polymyxa).

** RC: Rate of relative changes of the results, referring to the control "W.B.O ".

Composition of each of the submitted organic fertilizers determined their rate of mineralization in the tested soils. For instance, the narrower $\mathrm{C}: \mathrm{N}$ ratio of compost "CM" hastened the degradation rate of its organic compounds, as compared with the farmyard manure " FYM ". Presence of cattle dung and urine, as well as a soil portion (clay and silt) (as a bedding material) within the makeup of farmyard manure, contributed to some extent to the relatively higher contents of salts in the experimental components. Data appearing in Table 2 confirm this interpretation. Breakdown of the organic compounds composing the added organic fertilizers eventually results in accumulation of mineral elements and thus the contents of TSS are elevated in the soil medium (Tinsley \& Darbyshire, 1984, Parr et al., 1989, Barber, 1995 and Brady \& Weil, 2008). 
Participation of the bio-fertilizers in such concern was confined to their moderately activation of the decomposition of organic fertilizers added. Rates of TSS relative changes "RC" principally depended on soil properties, whereas the clayey soil exhibited higher values of TSS-RC than the sandy soils (see Tables 1 and $5 \mathrm{a} \& \mathrm{~b})$.

Noteworthy that, accumulation of TSS in soil, as long as their presence is at a moderate level, is a beneficial process, since most of those salts are plant nutrients, deriving from organic matter mineralization.

Effect of the bio-organic additives on microbial activity in soils (soil respiration "evolution of carbon dioxid")

Changes in soil respiration $\left(\mathrm{CO}_{2}\right.$ evolution), as a measure of the overall microbial activity in soil, under the impact of bio- organic additives, i.e. compost "CM" and farmyard manure "FYM", Bacillus megaterium "Bm" and Bacillus polymyxa " $B p$ ", at intervals throughout 120 days of experimental period of sandy and clayey soils, are presented in Table 6(a \& b). Data of Table 6a exhibited that, all the applied amendments significantly accelerated soil respiration with time in the sandy soil. Incorporation of CM or FYM increased the daily rate of $\mathrm{CO}_{2}$ evolution to attain $\mathrm{RC}$ values of $52 \& 34 \%$ above the control treatment, respectively. On the other hand, introduction of the biofertilizers $B m$ or $B p$ improved soil respiration in the same sandy soil by RC $16 \& 7 \%$, respectively.

The highest $\mathrm{RC}$ values of $\mathrm{CO}_{2}$ evolution in the sandy soil were obtained by submitting the dual additives of bio- and organic amendments, i.e. $\mathrm{CM}+\mathrm{Bm}$ were superior and descendingly followed by $\mathrm{CM}+B p$, as they gave RC rates of $104 \& 86 \%$ above the control, respectively. Combinations of FYM with any biofertilizer also increased soil respiration, but at lower extents than the CM counterparts, as the gained values, above the control, were of RC $72 \& 58 \%$ for $\mathrm{FYM}+B m$ and FYM+ $B p$, respectively. The mean RC rate of the total bioorganic treatments was $41 \%$ referring to the control treatment "W.B.O."

Resembling results of the sandy soil were detected for the clayey soil, concerning the pattern of $\mathrm{CO}_{2}$ evolution, but at higher rates (Table 6b). Addition of compost "CM" or farmyard manure "FYM", as organic fertilizers, and Bacillus megaterium "Bm" or Bacillus polymyxa " $B p$ ", as bio-fertilizers, all increased the soil respiration, to reach $\mathrm{RC}$ rates of $52 \& 35$ and $14 \& 6 \%$, respectively, above the control treatment.

Application of the combined additives of bio-organic substrates, significantly encouraged the discharge of $\mathrm{CO}_{2}$ in the clayey soil, when gave RC rates of $104 \& 86$ and $72 \& 58 \%$ above the control, with $\mathrm{CM}+\mathrm{Bm}, \mathrm{CM}+\mathrm{Bp}$, $\mathrm{FYM}+\mathrm{Bm}$ and FYM $+B p$, respectively (Table $6 \mathrm{~b}$ ). 
TABLE 6a. Rates of $\mathrm{CO}_{2}$ evolved from the rock phosphate treated Sandy soil, as affected by the bio-organic additives.

\begin{tabular}{|c|c|c|c|c|c|c|c|c|c|c|c|c|c|}
\hline \multicolumn{12}{|c|}{ Incubation Time (Days) } & \multirow{3}{*}{\multicolumn{2}{|c|}{ 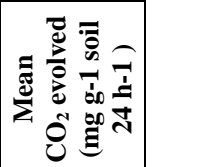 }} \\
\hline \multirow{2}{*}{\multicolumn{3}{|c|}{ Treatments * }} & $\mathbf{0}$ & 15 & 30 & 45 & 60 & 75 & 90 & 105 & 120 & & \\
\hline & & & \multicolumn{9}{|c|}{$\mathrm{CO}_{2}$ evolved (mg g ${ }^{-1}$ soil $\left.24 \mathrm{~h}^{-1}\right)$} & & \\
\hline \multicolumn{3}{|c|}{$\begin{array}{c}\text { Control "0" } \\
\text { (soil native } \\
\text { status ) } \\
\end{array}$} & 2.95 & 3.05 & 3.23 & 3.47 & 3.74 & 4.23 & 5.05 & 5.37 & 5.72 & 4.09 & \multirow[t]{2}{*}{$\begin{array}{r}\mathrm{RC} * \\
(\%)\end{array}$} \\
\hline \multirow{10}{*}{ 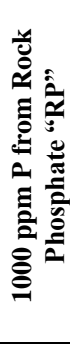 } & \multicolumn{2}{|c|}{ "W.B.O" } & 3.39 & 3.56 & 3.90 & 4.29 & 4.68 & 5.33 & 6.29 & 7.40 & 8.08 & 5.21 & \\
\hline & \multicolumn{2}{|c|}{ CM } & 4.29 & 5.01 & 5.33 & 5.66 & 8.23 & 8.32 & 10.44 & 11.69 & 12.22 & 7.91 & 52 \\
\hline & \multicolumn{2}{|l|}{ FYM } & 4.16 & 4.48 & 4.90 & 5.27 & 6.62 & 7.19 & 9.31 & 10.07 & 10.86 & 6.98 & 34 \\
\hline & \multicolumn{2}{|l|}{ B.M } & 3.55 & 3.91 & 4.45 & 4.58 & 5.50 & 6.38 & 8.15 & 8.65 & 9.20 & 6.04 & 16 \\
\hline & \multicolumn{2}{|l|}{ B.P } & 3.50 & 3.72 & 3.92 & 4.33 & 4.81 & 5.77 & 7.19 & 8.02 & 8.71 & 5.55 & 07 \\
\hline & \multirow{2}{*}{$\mathbf{C M}$} & B.M & 6.22 & 5.93 & 7.68 & 7.55 & 8.87 & 11.09 & 15.35 & 15.86 & 17.16 & 10.63 & 104 \\
\hline & & B.P & 5.80 & 6.26 & 7.13 & 6.65 & 7.90 & 9.95 & 13.01 & 14.73 & 15.60 & 9.67 & 86 \\
\hline & \multirow{2}{*}{ FYM } & B.M & 4.86 & 5.15 & 6.76 & 7.73 & 7.46 & 9.28 & 11.80 & 13.29 & 14.46 & 8.98 & 72 \\
\hline & & B.P & 4.82 & 4.82 & 6.09 & 5.73 & 8.03 & 8.53 & 10.91 & 11.98 & 13.23 & 8.24 & 58 \\
\hline & \multicolumn{2}{|c|}{\begin{tabular}{|l|} 
Mean \\
\end{tabular}} & 4.35 & 4.59 & 5.34 & 5.53 & 6.58 & 7.61 & 9.75 & 10.71 & 11.52 & 7.33 & 41 \\
\hline
\end{tabular}

L.S.D, at $0.05(0.60) \quad \& \quad$ L.S.D, at $0.01(0.90)$.

*W.B.O (without bio-organic addition), CM ( compost ), FYM ( farmyard manure), Bm (Bacillus megaterium), Bp (Bacillus polymyxa).

** RC: Rate of relative changes of the results , referring to the control "W.B.O “.

TABLE 6b. Rates of $\mathrm{CO}_{2}$ evolved from the rock phosphate treated clayey soil, as affected by the bio-organic additives.

\begin{tabular}{|c|c|c|c|c|c|c|c|c|c|c|c|c|c|}
\hline \multicolumn{12}{|c|}{ Incubation Time (Days) } & \multirow{3}{*}{\multicolumn{2}{|c|}{ 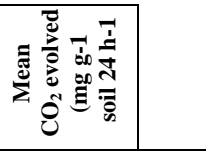 }} \\
\hline \multirow{2}{*}{\multicolumn{3}{|c|}{ Treatments * }} & $\mathbf{0}$ & 15 & 30 & 45 & 60 & 75 & 90 & 105 & 120 & & \\
\hline & & & \multicolumn{9}{|c|}{$\mathrm{CO}_{2}$ evolved (mg g ${ }^{-1}$ soil $\left.24 \mathrm{~h}^{-1}\right)$} & & \\
\hline \multicolumn{3}{|c|}{$\begin{array}{c}\text { Control "0" } \\
\text { (soil native } \\
\text { status ) } \\
\end{array}$} & 4.14 & 4.31 & 4.65 & 5.00 & 5.47 & 6.41 & 7.99 & 8.55 & 8.94 & 6.16 & \multirow{2}{*}{$\begin{array}{r}\mathbf{R C} \\
* * \\
(\%) \\
\end{array}$} \\
\hline \multirow{10}{*}{ 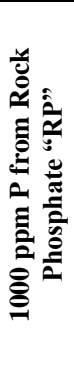 } & \multicolumn{2}{|c|}{ "W.B.O" } & 4.76 & 4.98 & 5.38 & 5.92 & 6.62 & 8.02 & 9.88 & 11.17 & 12.46 & 7.69 & \\
\hline & \multicolumn{2}{|c|}{ CM } & 6.26 & 6.85 & 7.74 & 8.32 & 9.82 & 12.38 & 16.13 & 18.31 & 19.37 & 11.69 & 52 \\
\hline & \multicolumn{2}{|l|}{ FYM } & 6.07 & 6.36 & 7.03 & 7.37 & 8.85 & 10.55 & 14.29 & 15.69 & 17.01 & 10.36 & 35 \\
\hline & \multicolumn{2}{|c|}{ Bm } & 5.03 & 5.63 & 6.07 & 6.42 & 7.30 & 9.30 & 12.09 & 12.83 & 14.07 & 8.75 & 14 \\
\hline & \multicolumn{2}{|l|}{$B p$} & 4.90 & 5.18 & 5.49 & 6.05 & 6.98 & 8.52 & 10.76 & 12.07 & 13.21 & 8.13 & 06 \\
\hline & \multirow{2}{*}{$\mathbf{C M}$} & $B m$ & 8.38 & 9.03 & 10.51 & 11.65 & 13.89 & 17.75 & 22.86 & 26.03 & 28.13 & 16.47 & 114 \\
\hline & & $B p$ & 7.74 & 8.08 & 9.44 & 10.21 & 12.27 & 15.79 & 20.88 & 22.98 & 25.17 & 14.73 & 92 \\
\hline & \multirow{2}{*}{ FYM } & $B m$ & 7.30 & 7.89 & 8.86 & 9.74 & 11.59 & 14.72 & 19.01 & 21.51 & 23.61 & 13.80 & 79 \\
\hline & & $B p$ & 7.01 & 7.22 & 8.56 & 8.75 & 10.55 & 13.53 & 17.47 & 19.35 & 21.77 & 12.69 & 65 \\
\hline & \multicolumn{2}{|c|}{ Mean } & 6.16 & 6.55 & 7.37 & 7.94 & 9.33 & 11.70 & 15.14 & 16.85 & 18.37 & 11.05 & 44 \\
\hline
\end{tabular}

*W.B.O (without bio-organic addition), CM (compost), FYM ( farmyard manure), Bm (Bacillus megaterium), Bp (Bacillus polymyxa).

**RC: Rate of relative changes of the results, referring to the control "W.B.O ".

Egypt. J. Soil Sci. 55, No. 4 (2015) 
Evolution of $\mathrm{CO}_{2}$ is the major outcome of organic matter decomposition in soil, as it represents the respiration of the chemoorganotrophic microorganisms dominating in soils. Hence it reflects the overall biochemical activity in a soil. The heterotrophic microorganisms, including the phosphate dissolving bacteria, derive their carbon and energy from organic sources, and thus all participate in the breakdown of such materials and emission of $\mathrm{CO}_{2}$. Consequently, the applied bio-organic fertilizers favour the availability of phosphate in soil, also via formation of carbonic acid from the produced $\mathrm{CO}_{2}$, as well as other organic acids (Barber, 1995 and Kiran \& Phogat, 2008).

It is well established that, phosphorus "P" plays an indispensable biochemical role in photosynthesis, respiration, energy storage and transfer, cell division, cell enlargement and several other processes in the living organisms. An adequate supply of phosphorus at the first stages of plant growth promotes physiological functions including early root formation, and is important for laying down the primordia for reproductive parts of plants. It is vital to seed formation and its content is higher in seeds than in any other part of the plant. It helps plants to survive winter rigors and also contributes to disease resistance in some plants. Also, it is known to improve quality of many fruits, vegetables and grain crops. Biological nitrogen fixation depends appreciably on the available forms of phosphorus. Phosphorus is an important structural constituent of nucleic acids, phytin and phospholipids (Richa, 2003).

The mobility of $\mathrm{P}$ in soil is low compared to other plant nutrients because of the generally low solubility of phosphate compounds and the strong P-binding capacity of soil material (Sibberson and Sharpley, 1997). Organic P is an important fraction of soil P, but, because roots take up $\mathrm{P}$ in the form of orthophosphate, any organic P compounds in the soil solution must first be mineralized before the uptake can happen. The area in the immediate vicinity of the roots "the rhizosphere", harbouring various microorganisms, can differ from the bulk soil in terms of its $\mathrm{pH}, \mathrm{CO}_{2}$ partial pressure, enzyme activity and cation and anion activities (Jungk, 1987 and Ghani et al., 1994), and the processes occurring in this zone determine the immediate availability of $\mathrm{P}$ to the plants roots.

Consequently, presence of adequate amounts of soluble phosphate in soil is of utmost necessity for plant growth and microbial proliferation in favour of a better crop production. To ensure such situation, application of manures and biofertilizers to the soil should be a recommended ordinary agricultural practice. Manures (organic fertilizers) are main sources of organic phosphorus which is released into the soil via decomposition of its organic compounds. Biofertilizers, represented by certain microorganisms, participate in phosphate solubility in soil via their ability to produce a variety of organic acids. As well as, libration of $\mathrm{CO}_{2}-$ forming carbonic acid and various organic acids through the breakdown of applied organic materials contributes to the solubility of phosphate in soil and other plant nutrients, as well (Kucey et al., 1989, Kpomblekou \& Tabatabai, 1994 and Khan et al., 2007). Soil properties severely contribute to phosphate availability, particulary via 
texture, $\mathrm{pH}$ value and content of $\mathrm{CaCO}_{3}$ (Tisdale et al., 1993 and Kiran \& Phogat, 2008). This was the reason of the better results shown by the clayey soil in most cases than those of the sandy soil, in the present study.

\section{References}

Barber, SA. (1995) Soil Nutrient Bioavailability. John Wiley \& Sons Inc. New York, USA.

Brady, N.C. and Weil, R.R. (2008) The Nature and Properties of Soils. $14^{\text {th }}$ ed. Pearson/Prentice Hall.

Chen, Y.P., Rekha, P.D., Arunshen, A.B., Lai, W.A. and Young, C.C. (2006) Phosphate solubilizing bacteria from subtropical soil and their tricalcium phosphate solubilizing abilities. Appl. Soil Ecol., 34, 33-41.

Collins, C.H. and Lyne, P.M. (1980) Microbiological Methods, Butter worth World Pub. Co. London, UK.

Cottenie, A., Verloo, M., Kiekens, L.,Velghe, G. and Camerlynck, R. (1982) Chemical Analysis of Plant and Soils. Laboratory of Analytical and Agrochemistry, State University of Gent, Belgium.

Das, S.K., Sharma, K.L., Srinivas, K., Narayana, R.M. and Singh, O.H. (1995) Phosphorous and sulfur availability in soil following incorporation of various organic residues. J. Ind. Soc. Soil Sci., 43 (2), 223 - 228.

Ghani, A., Rajan, S. and Lee, A. (1994) Enhancement of rock phosphate solubility through biological processes. Soil Biol. Biochem., 26, 127-136.

Jungk, A. (1987) Soil-root interactions in the rhizosphere affecting plant availability of phosphorus. J. of Plant Nutrition, 10, 1197-1204.

Khan, M.S., Zaidi, A. and Wani, P.A. (2007) Role of phosphate-solubilizing microorganisms in sustainable agriculture- a review. Agron. Sustain. Dév., 27, 29-43.

Kiran, K. and Phogat, V. K. (2008) Rock phosphate: its availability and solubilization in the soil - a review. Agric. Rev., 29 (2),108 -116.

Klute, A. (1986) Methods of Soil Analysis.Physical and Mineralogical Properties. Amer. Soc. Agron. Inc. Madison, Wisc., USA.

Kpomblekou, K. and Tabatabai, M.A. (1994) Effect of organic acids on release of phosphorus from phosphate rocks. Soil Sci., 158, 442-453.

Kucey, R.M.N., Janzen, H.H. and Legget, M.E. (1989) Microbial mediated increases in plant available phosphorus. Adv. Agron., 42, 199 -228.

Lindsay, W.L. (1979) Chemical Equilibria in Soils. Wiley-Interscience Publication.

Muhammad, M.A. and Maram, G. (2012) The effect of phosphate solubilizing bacteria and organic fertilization on availability of Syrian rock phosphate and increase of triple superphosphate efficiency. World J. Agric. Sci., 8 (5), 473-478.

Egypt. J. Soil Sci. 55, No. 4 (2015) 
Nahas, E. (1996) Factors determining rock phosphate solubilization by microorganisms isolated from soil. World J. Microbiol. Biotech., 12, 567-572.

Paul, E. and Clark, F. (1996) Soil Microbiology and Biochemistry, Academic Press. New York, USA.

Parr, J.F., Papendirick, R.I. and Colacicco, D. (1989) Use of organic amendments for increasing productivity of arid land. Arid Soil Res. Reh., 3, 149-170.

Richa, G. Ms. (2003) Rock phosphate and phosphate solubilizing microbes as a source of nutrients for crops.M.Sc in Biotechnology. Thapar Institute of Engineering and Technology.

Richardson, A.E. (2001) Prospects for using soil microorganisms to improve the acquisition of phosphorus by plants. Aust. J. Plant Physiol., 28, 897-906.

Sendecor, G.W. and Cochran, W. (1980) Statistical Methods. $7^{\text {th }}$ ed., Aiwa State Univ. Press. Ames, Aiwa, USA.

Sibberson, E. and Sharpley, A.N. (1997) Setting and justifying upper critical limits for phosphorus in soils. In: Tunney, H., Carton, O.T., Brookes, P.C. and Johnson, A.E. (Ed). Phosphorus Loss from Soil to Water, CAB Int, Oxon, UK.

Simpson, P.G., Sale, P.W.G. and Tennakoon, S.B. (1997) An economic analysis of the field performance of North Carolina reactive phosphate rock compared with single superphosphate for selected sites from the National Reactive Phosphate Rock Project. Austr. J. Exp. Agric., 37, 1061-1076.

Singh, C.P. and Amberger, A. (1997) The effect of rock phosphate-enriched compost on the yield and phosphorus nutrition of rye grass. Amer. J. Agric., 82-87.

Taalab, A.S. and Badr, M.A. (2007) Phosphorus availability from compacted rock phosphate with nitrogen to Sorghum inoculated with phospho-bacterium. J. Appl. Sci. Res., 3 (3), 195-201.

Tinsley, J. and Darbyshire, J.F. (1984) Biological Processes and Soil Fertility. Kluwer Acad. Publ. Group. Boston, USA.

Tisdale, S.L., Nelson, W.L., Beaton, J.D. and Havlin, J.L. (1993) Soil Fertility and Fertilizers, $5^{\text {th }}$ ed. Mcmillan Publ. Co., New York.

Vassilev, N., Medina, A., Azcon, R. and Vassileva, M. (2006) Microbial solubilization of rock phosphate on media containing agro-industrial wastes and effect of the resulting products on plant growth and $\mathrm{P}$ uptake. First International Meeting on Microbial Phosphate Solubilization Proc., 77-84.

Youssef, F.G., L.R. Macdowell, L.R. and Brathwail, R.A.I. (1999) The status of certain trace minerals and sulphur of some tropical grasses in Trinidad. Trop. Agric. (Trinidad), 76, 57-62. 


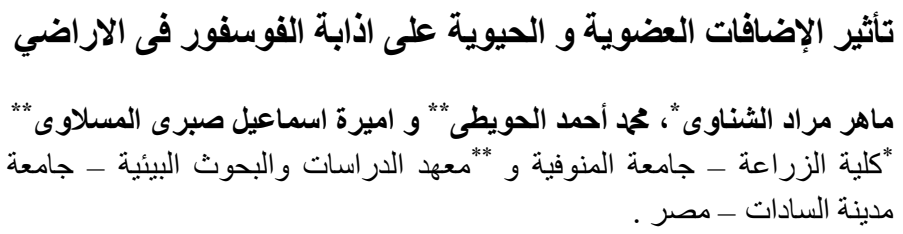

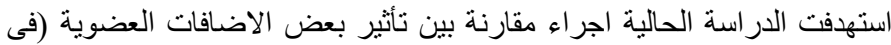

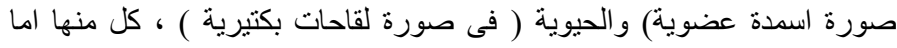

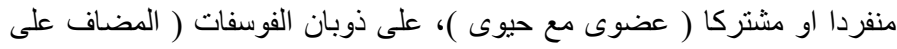

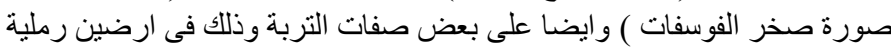

ورسوبية . وشملت الدر اسة المو اد التاليه:

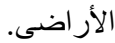

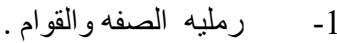
2- رسوبيه طينية القوام .

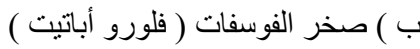

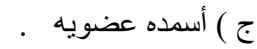

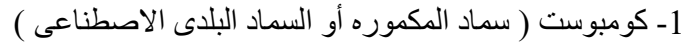

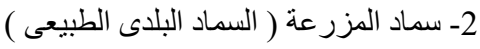

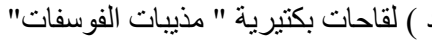

. Bacillus megaterium "Bm" -1 . Bacillus polymyxa " $\mathrm{Bp}$ " -2

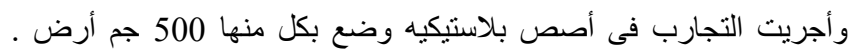

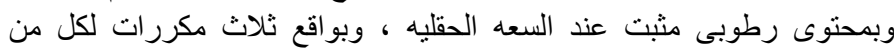
المعاملات التاليه .. 1- أرض كنترول " Control 0 " بدون أية اضافات ( فوسفاتية ، عضوية أو بكتيرية (ارضية

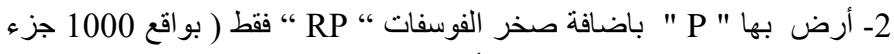

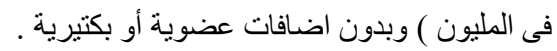

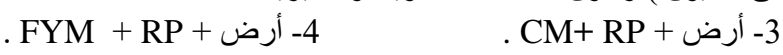
79- أرض +

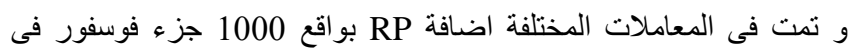

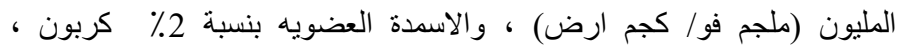

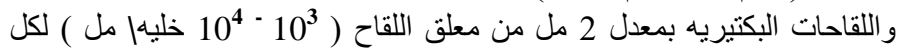

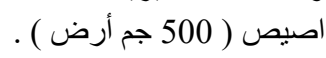




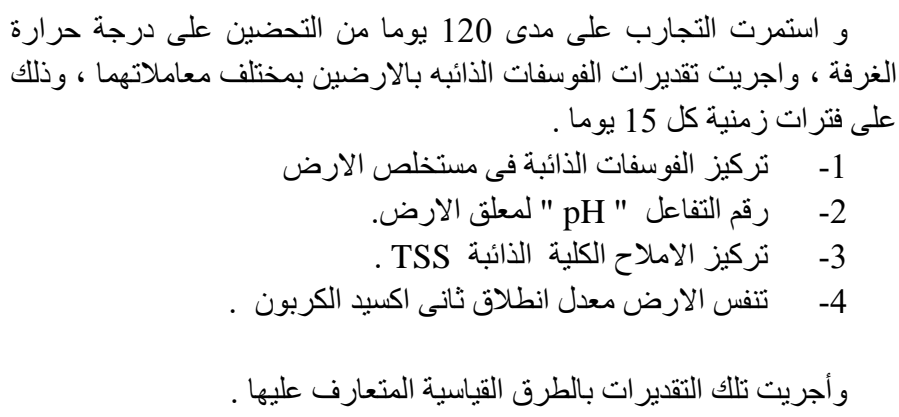

